Юнина В.В.

\title{
Содержание воспитательной среды детей с ограниченными возможностями здоровья \\ в условиях школы
}

Целенаправленное и осознанное формирование воспитательной среды учреждения, где проводят большую часть своей жизни дети, является делом чрезвычайной важности для любой, в том числе и для коррекционной, школы [4; 5]. Воспитательная среда - важнейший фактор школьной жизни, поскольку задаёт общечеловеческое основание жизнедеятельности ребёнка в сообществе [3]. Среда окружения человека определяет образ его жизни, под влиянием которого формируются установки, ценности, стереотипы [1]. Далеко не всякая среда становится средством воспитания. Часто ребенок с ограниченными возможностями здоровья находится в отчужденном состоянии и не осваивает эту среду, особенно если она не соответствует его особым образовательным потребностям [2]. Поэтому целью нашей экспериментальной работы явилось определение содержания воспитательной среды детей с ограниченными возможностями здоровья. Эксперимент осуществлялся в ГОУ лО «Сиверская специальная (коррекционная) школа - интернат Ленинградской области. В эксперименте приняли участие 140 детей в возрасте от 7 до 17 лет с отклонениями в умственном развитии, 30 педагогов, 46 родителей. Сочетание теоретико - методологического уровня исследования с решением задач прикладного характера обусловило выбор методов работы, включающих анализ философской, педагогической и психологической литературы по проблеме; анализ педагогического опыта специальных и общеобразовательных учреждений; педагогический эксперимент (констатирующий и формирующий); прогнозирование и конструирование модели воспитательной среды в специальной школе.

Как мы считаем, среда коррекционно - образовательного учреждения будет воспитательной, если она может быть охарактеризована, как система специально организованных психолого - педагогических условий, обеспечивающихэффективную жизнедеятельность учащегося в прочессе обучения, и направленная на расширение возможностей его социализации.

Результаты проведённого нами исследования позволили выделить основные компоненты воспитательной среды как системы специально организованных психолого - педагогических условий:

1.Социально - культурный (художественно-творческий) компонент.

Целью социально-культурной реабилитации является повышение уровня социальной адаптации и интеграции человека, расширение его социальных связей, восстановление его социального статуса как активного члена общества. Особенно это значимо для детей с проблемами в развитии. В рамках данного направления решаются следующие задачи: 
- реализация социализирующего, развивающего потенциала культурнодосуговой деятельности путем создание условий для полноценного проведения досуга, самовыражения и самоутверждения, духовно насыщенного общения, творческой самореализации ребенка с отклонениями в умственном развитии.

- развитие личности и формирование потребности в личностном самосовершенствовании, саморазвитии путем включения в различные виды социально-культурного творчества;

- развитие новых и поддержка традиционных форм досуговой деятельности;

- организация разностороннего общения подростков на основе общности интересов. Формой реализации данного направления являются: школьная художественная самодеятельность; молодежные клубы; группы художественного развития, разрабатывающие специальные социо-культурные программы и проекты («Школа общения», «Школа жизни» и др.), в которые включаются интерактивные, диалоговые, игровые и другие методики.

\section{2. Психолого - реабилитационный компонент.}

Цель данного компонента - формирование психических качеств и способностей ребенка с отклонениями в умственном развитии, обеспечивающих его мотивационную готовность и успешность в различных сферах деятельности. Основными задачами программ психологической реабилитации являются следующие:

- восстановление и развитие психических функций (памяти мышления, интеллекта, психомоторики, и др.);

- снижение уровня локальных эмоциональных расстройств (возбудимости, тревожности, эмоциональной неустойчивости и т.д.);

- развитие навыков и способностей к волевым усилиям и психической саморегуляции;

- формирование адекватного отношения к собственному «Я» (адекватной самооценки, понимания своих проблем и возможностей);

- развитие навыков творческого самовыражения и принятия решений.

Психолого-реабилитационные программы реализовываются через следующие формы: психотерапия; игротерапия; библиотерапия; психологический тренинг и др.

\section{3. Социально адаптационный компонент.}

Цель данного направления работы состоит в организации помощи ребенку с отклонениями в умственном развитии в социокультурной адаптации. Основные задачи:

- повышение коммуникативной культуры личности;

- формирование ценностных ориентаций и активной жизненной позиции;

- расширение круга интересов;

- оптимизация отношений в семье. 
Ведущая форма выработки навыков взаимодействия ребенка с социумом социально-психологический тренинг, в рамках которого происходит отработка социальных навыков и специфических социальных умений, таких как поиск работы, рассматриваются взаимоотношения в семье, дружба, приятельство и т.д.

\section{4. Физкультурно - оздоровительный компонент.}

Цель данного направления - использование социализирующего и реабилитационного потенциала физической культуры. Задачи направления:

- пропаганда физической культуры и здорового образа жизни;

- повышение общего уровня физической подготовленности детей, сохранение и укрепление их здоровья;

- пропаганда народных средств оздоровления и традиционных оздоровительных систем;

- формирование глубоких и полных знаний о своем физическом состоянии и путях его улучшения с учетом реальных проблем и потребностей ребенка.

Основные формы: организация и проведение физкультурно-оздоровительных программ; проведение лечебно-оздоровительных мероприятий, организация физкультурно-реабилитационных групп; проведение спортивных, семейных праздников, спортивно-игровых программ; оказание оздоровительных и медицинских услуг.

\section{5. Профессионально - ориентационный компонент.}

Целевая установка этого направления в подготовка человека к самостоятельной трудовой жизни в реальных условиях рыночной экономики, помощь в овладении знаниями, умениями и навыками в области рекомендуемой профессии. Задачи профессионально-ориентационного направления:

- обеспечить адекватное профессиональное самоопределение (выбор профессии в соответствии с индивидуальными возможностями личности и запросами общества);

- сформировать ценностные ориентации, мотивы и установки по отношению к определенным видам профессиональной деятельности;

- воспитывать трудолюбие, развивать инициативу, предприимчивость, творчество.

Формы реализации программ, обеспечивающих профессиональное самоопределение - включение подростка в различные виды ролевых игр, направленных на развитие предприимчивости, трудовой деятельности в производственных мастерских, предпринимательских мини-фирмах, производственных кооперативах (в том числе и совместного труда с родителями, сверстниками, педагогами).

\section{6. Учебно-образовательный компонент.}

Цель этого направления является интегрирование детей с отклонениями в развитии в сферу образования, обеспечение им необходимых условий для полно- 
ценного обучения, культурного развития, и дальнейшего профессионального самоопределения. Задачами данного направления деятельности являются:

- совершенствование научных и методических основ реабилитационной и адаптационной работы;

- обобщение и распространение инновационных методик и прогрессивных технологий комплексной реабилитации детей с отклонениями в развитии.

Формами данного направления являются организация в условиях школы клубов, музея, конференций, семинаров (для родителей, специалистов сферы образования, исполнителей программ).

\section{7.Правовой компонент.}

Цель - защита и представление интересов ребенка с отклонениями в развитии в обществе. В качестве задач выделены следующие:

- организация мероприятий социально-политического характера, направленных на изменение отношений общества и власти к проблемам детей данной категории;

- изменение социальной политики по отношению к проблемным детям;

- усиление гуманистической направленности отношения к детям с проблемами в интеллектуальном развитии со стороны общества и отдельных людей;

- развитие опыта социального партнерства.

Изменение отношения общества к ребенку осуществляется в процессе реализации государственных социальных программ; организации социального контроля за сферой формирования общественного мнения. Конкретными формами деятельности по социальной поддержке являются: разработка и реализация адресных программ материальной помощи детям из малообеспеченных семей, оказание правовой и консультационной помощи, создание рабочих мест для таких детей, сезонное трудоустройство подростков и их родителей, выделение в СМИ рубрик социальных проблем детей данной категории.

\section{Литература}

1. Актуальные вопросы теории и практики коррекционной педагогики. Межвузовский сборник научных трудов. - М. МГОПУ, 1997.

2. Воспитательная система школы. Сб.ст. / Отв. ред. Л.И. Новикова. М. Пед. общество РСФСР. 1991.

3. Селиванова Н.Л. Концептуальные основы теории воспитательных систем//Школьный вестник. 2001. №2/6

4. Дульнев Г.Д. Учебно - воспитательная работа во вспомогательной школе. Пособие для учителя. / под ред. Т.А.Власовой и В.Г. Петровой. - М. Просвещение. 1981.

5. Цветкова И.В. Как создать программу воспитательной работы. Метод. пособие. М. Просвещение. 2006. 